\title{
Identification of Fruit Tree Compositions in Public Parks Structure. Warsaw Case Study
}

\author{
Tabita-Teodora LISANDRU ${ }^{1 *}$, Kinga KIMIC ${ }^{2}$ and Viorel MITRE ${ }^{1}$ \\ ${ }^{1}$ Department of Horticulture and Landscape Architecture. University of Agricultural Sciences and \\ Veterinary Medicine, Calea Mănăștur 3-5, Cluj-Napoca 400372, Romania \\ ${ }^{2}$ Department of Landscape Architecture. Warsaw University of Life Sciences - SGGW, Nowoursynowska \\ Street 166, 02-787 Warsaw, Poland \\ *)Corresponding author, e-mail: tabita.lisandru@usamvcluj.ro
}

BulletinUASVM Horticulture 73(2) / 2016

Print ISSN 1843-5254, Electronic ISSN 1843-5394

DOI:10.15835/buasvmcn-hort:12236

\begin{abstract}
Fruit trees are essential components of different types of greenery, including not only private gardens but also historical and modern public parks and gardens of many other cities. The research was carried out in spring 2016 by visiting different parks. Fruit trees were identified in 22 public parks of Warsaw situated in different districts of the city and picked up randomly for preliminary study. Observations were made by photographic documentation and mapping of the fruit trees on park plans using GPS coordinates which were taken during the site visit and Google Earth maps. According to the observations, selected fruit trees compositions have been recognized in public parks of Warsaw. The compositional structures that have been observed consist of solitaire fruit trees, groups of trees (containing fruit trees, but mostly composed of fruit trees and ornamental shrubs) and linear structures of fruit trees (rows and alleys). The results of the preliminary study show that the most frequent fruit tree compositions used in the structure of selected public parks of Warsaw represent groups of trees - groups that consist of fruit trees and different species of ornamental shrubs. The undertaken study confirmed that fruit trees planted in the public parks of Warsaw have a high compositional value. They play an important role in the spatial arrangement of the parks selected, but also define the scope and borders of the selected garden interiors and create attractive sites.
\end{abstract}

Keywords: composition, fruit trees, public parks, value, Warsaw

\section{INTRODUCTION}

Trees planted in gardens and parks represent different species, forms and arrangements, which has been determined by development of styles and trends in garden art history throughout the ages (Hobhouse, 2004). They are long-lived and the biggest plants in all types of public greenery and their fundamental components, including public parks and gardens (Stagoll et.al., 2012).

Fruit trees represent a specific group of trees and they play a significant role in the history of Polish garden art. First of all they were recognized and described in relation to agricultural aspects including the development of the species and cultivars planted in orchards, also in royal and private gardens since medieval times (Majdecki, 2008, 2009). Their ornamental values were presented very rarely (Zachariasz, 2012). The ability of their application to public spaces were perceived at the end of $19^{\text {th }}$ and early $20^{\text {th }}$ centuries due to the development of the trends related to fruit trees planting along roads (Petzold, 1880; Jankowski, 1921, 1930; Baster, 2010). Much less attention was paid to the context of fruit trees application to individual works related to artistic phenomenon or tendencies of residential gardens design (Zachariasz, 2012). The issues of compositional functions and values of fruit trees in public greenery were not developed too much in scientific literature in the last years. 
Tab. 1. The investigated public parks of Warsaw with fruit trees

\begin{tabular}{cccc}
\hline No. & Park name & Warsaw district & Park area [ha] \\
\hline 1. & Dolinka Służewiecka Park & Mokotów & 22.80 \\
\hline 2. & Kaskada Park & Żoliborz & 6.06 \\
\hline 3. & Kępa Potocka Park & Bielany / Żoliborz & 11.50 \\
\hline 4. & Krasińskich Garden & Śródmieście & 9.20 \\
\hline 5. & Łazienki Królewskie Park & Śródmieście & 76.00 \\
\hline 6. & Marszałka Edwarda Rydza-Śmigłego Park & Śródmieście & 53.00 \\
\hline 7. & Moczydło Park & Wola & 19.94 \\
\hline 8. & Morskie Oko Park & Mokotów & 17.90 \\
\hline 9. & Nad Balatonem Park & Praga Południe & 3.20 \\
\hline 10. & Pole Mokotowskie Park & Ochota / Mokotów / Śródmieście & 68.54 \\
\hline 11. & Praski Park & Praga Północ & 16.70 \\
\hline 12. & Romana Kozłowskiego Park & Ursynów & 11.60 \\
\hline 13. & Sady Żoliborskie Park & Żoliborz & 3.60 \\
\hline 14. & Saski Garden & Śródmieście & 15.49 \\
\hline 15. & Skaryszewski Park & Praga Południe & 49.56 \\
\hline 16. & Stefana Żeromskiego Park & Żoliborz & 6.00 \\
\hline 17. & Świętokrzyski Park & Śródmieście & 6.00 \\
\hline 18. & Edwarda Szymańskiego Park & Wola & 20.45 \\
\hline 19. & Ujazdowski Park & Śródmieście & 5.70 \\
\hline 20. & Waszyngtona Park & Praga Południe & 23.28 \\
\hline 21. & Wilanowski Park & Wilanów & 45.00 \\
\hline 22. & Zbigniewa Herberta Park & Bielany & 4.80 \\
\hline & & &
\end{tabular}

Warsaw is one of the greenest European capital cities. Public parks cover over 715 ha and became important elements of the green urban infrastructure of Warsaw together with other types of private and public urban greeneries. They were laid out in different ages and reflect different styles of composition (baroque, romantic, landscape and modern gardens) representing the tradition of park development in Warsaw. Different tree species are important elements of these compositions even nowadays. Fruit trees in public parks of Warsaw have different origins. Some of them are remnants of historical tradition or former allotment gardens adapted to public greenery; others were consciously used by designers or spontaneously planted by city dwellers as results of social initiatives. Fruit trees have an utilitarian function and an ecological role in the cities (Barthel et.al., 2015; Draper and Friedman, 2010; Speaka et.al., 2015). Despite this valuable background information, the compositional values of fruit trees in public parks have not been adequately studied.

\section{MATERIALS AND METHODS}

The main aim of this research was to identify fruit trees in public parks of Warsaw and determine the types of plant compositions that can be found in park structure.

The research was carried out in the historical and modern public parks of Warsaw, the capital of Poland. Fruit trees were identified in 22 public parks situated in different districts of the city and selected randomly for preliminary study (Tab.1). Site visits took place in April and May of 2016. This period of the year was chosen to follow also the bloom season of the trees. The parks were mapped in accordance with GPS coordinates which were taken during the site visit in order to prepare site plans of them with all the identified fruit tree location using Google Earth maps. At the same time, photographic documentation was made of all identified fruit trees in all of the parks selected for observation. Based on the gathered information further analysis was performed in order to identify different types of fruit trees arrangements observed in public parks structures. 
Tab. 2. Fruit tree compositions observed in the public parks of Warsaw

\begin{tabular}{|c|c|c|c|c|}
\hline No. & Park Name & Single tree & Group of trees & Linear structure of trees \\
\hline 1. & Dolinka Służewiecka Park & $\times$ & $\times$ & \\
\hline 2. & Kaskada Park & $x$ & & \\
\hline 3. & Kępa Potocka Park & $x$ & $x$ & \\
\hline 4. & Krasińskich Garden & $x$ & $x$ & $x$ \\
\hline 5. & Łazienki Królewskie Park & $x$ & $x$ & $x$ \\
\hline 6. & Marszałka Rydza-Śmigłego Park & $\times$ & $\times$ & \\
\hline 7. & Moczydło Park & $x$ & $x$ & $x$ \\
\hline 8. & Morskie Oko Park & $\times$ & $x$ & \\
\hline 9. & Nad Balatonem Park & & $\times$ & \\
\hline 10. & Pole Mokotowskie Park & $x$ & $x$ & $x$ \\
\hline 11. & Praski Park & $\times$ & $\times$ & \\
\hline 12. & Romana Kozłowskiego Park & & $x$ & \\
\hline 13. & Sady Żoliborskie Park & & $\times$ & \\
\hline 14. & Saski Garden & & $\times$ & \\
\hline 15. & Skaryszewski Park & $x$ & $x$ & $x$ \\
\hline 16. & Stefana Żeromskiego Park & $x$ & & \\
\hline 17. & Świętokrzyski Park & & $x$ & \\
\hline 18. & Szymańskiego Park & $\times$ & $\times$ & \\
\hline 19. & Ujazdowski Park & $x$ & $x$ & \\
\hline 20. & Waszyngtona Park & $x$ & $x$ & $x$ \\
\hline 21. & Wilanow Park & $x$ & $x$ & \\
\hline 22. & Zbigniewa Herberta Park & $x$ & $x$ & \\
\hline
\end{tabular}

\section{RESULTS AND DISCUSSION}

In this study 3 main types of plant compositions were observed specific to the 22 selected public parks structure of Warsaw. Among the compositions the dominant ones were as follow:

- single tree - fruit trees planted separately from other plants and plant compositions; located in general on lawns and meadows in parks;

- group of trees - including small groups of fruit trees or big groups consisting of fruit trees and other tree species or shrubs; located in different places in parks;

- linear structure of fruit trees - including single rows of fruit trees and alleys; located especially along the walkways.

Only one type of all 3 identified fruit tree compositions were recognized in 7 parks (they were represented by groups of trees or single trees); two types of fruit tree compositions were identified in 9 parks (in each case they represented both: single trees and group of trees) and all three types of fruit tree compositions were identified only in 6 parks.

The results regarding the identification of fruit tree compositions in public parks of Warsaw are presented below (Tab.2).

The results show that the predominant fruit tree compositions found in the public parks of Warsaw are groups of trees having in their composition different plants species. This type of fruit tree compositions were recognized in 20 of 22 parks (ex. Moczydło Park, Fig.1). The second commonly used compositions of fruit trees are single trees which were observed in 17 of 22 parks (ex. Waszyngtona Park, Fig.2). Linear structures of fruit trees are less frequent in public parks' compositions; they were identified only in 6 out of 22 parks studied (ex. Pole Mokotowskie Park, Fig.3).

The results of this research on fruit tree compositional values in the context of Polish garden art history development (Majdecki, 2008, 2009) have been focused for many years only on 


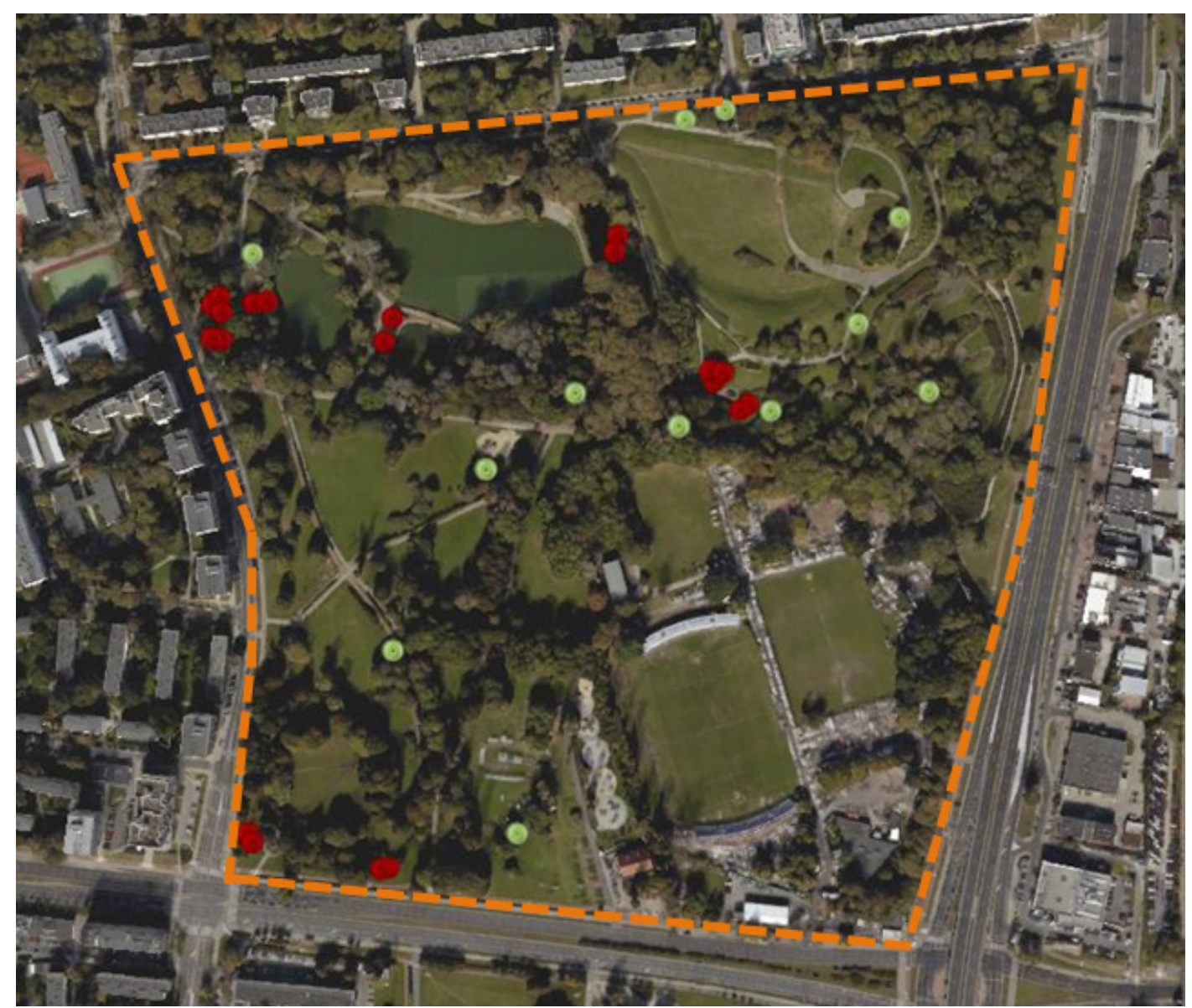

a.

Legend: $\begin{gathered}\text { a. } \\ \text { Single trees } \\ \text { Group of trees }\end{gathered}$

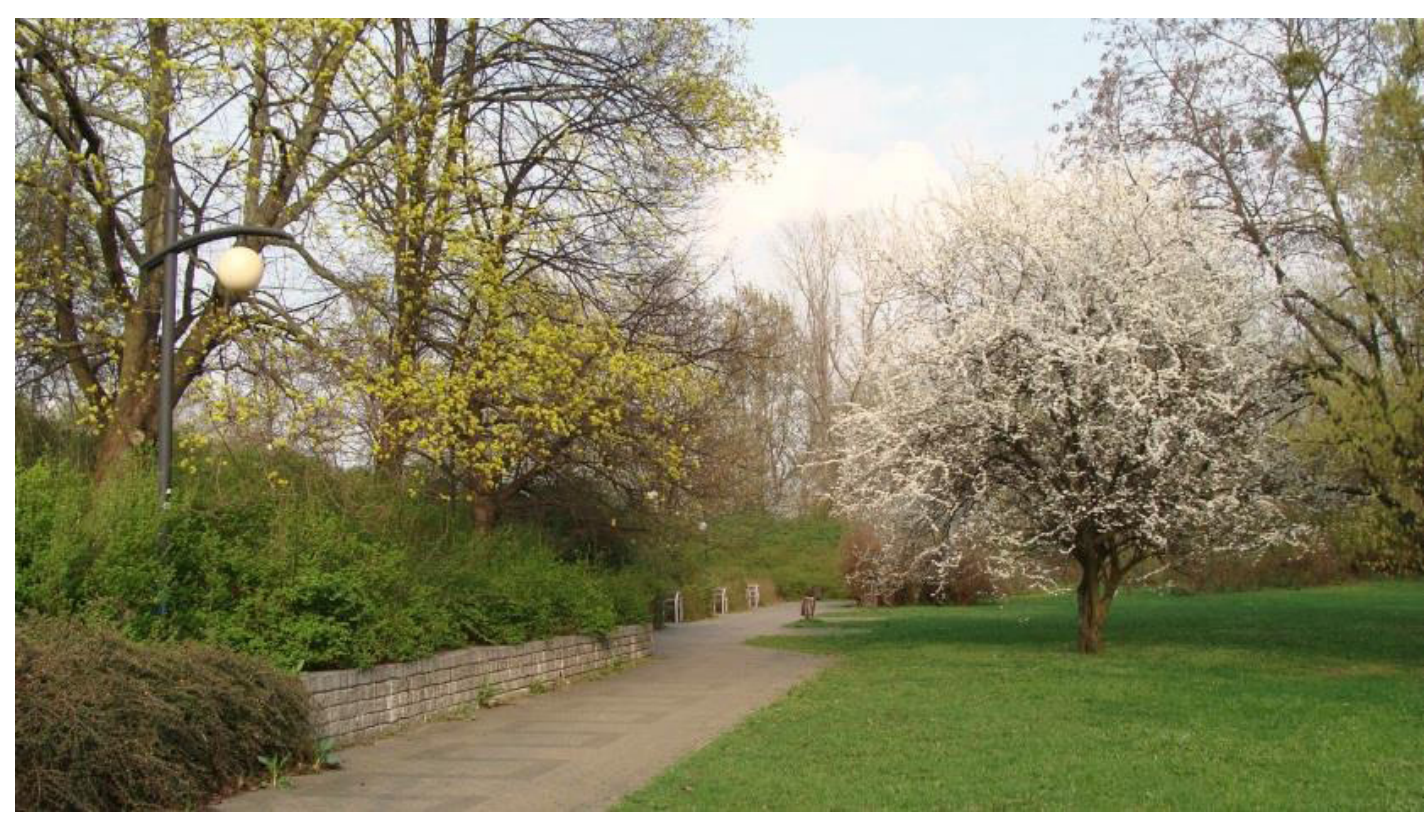

b.

Fig. 1. Moczydło Park, Warsaw: a) Site plan of the park with fruit tree compositions, b) Park perspective with single fruit tree planted in the park

(graphic and photo by T. Lisandru) 


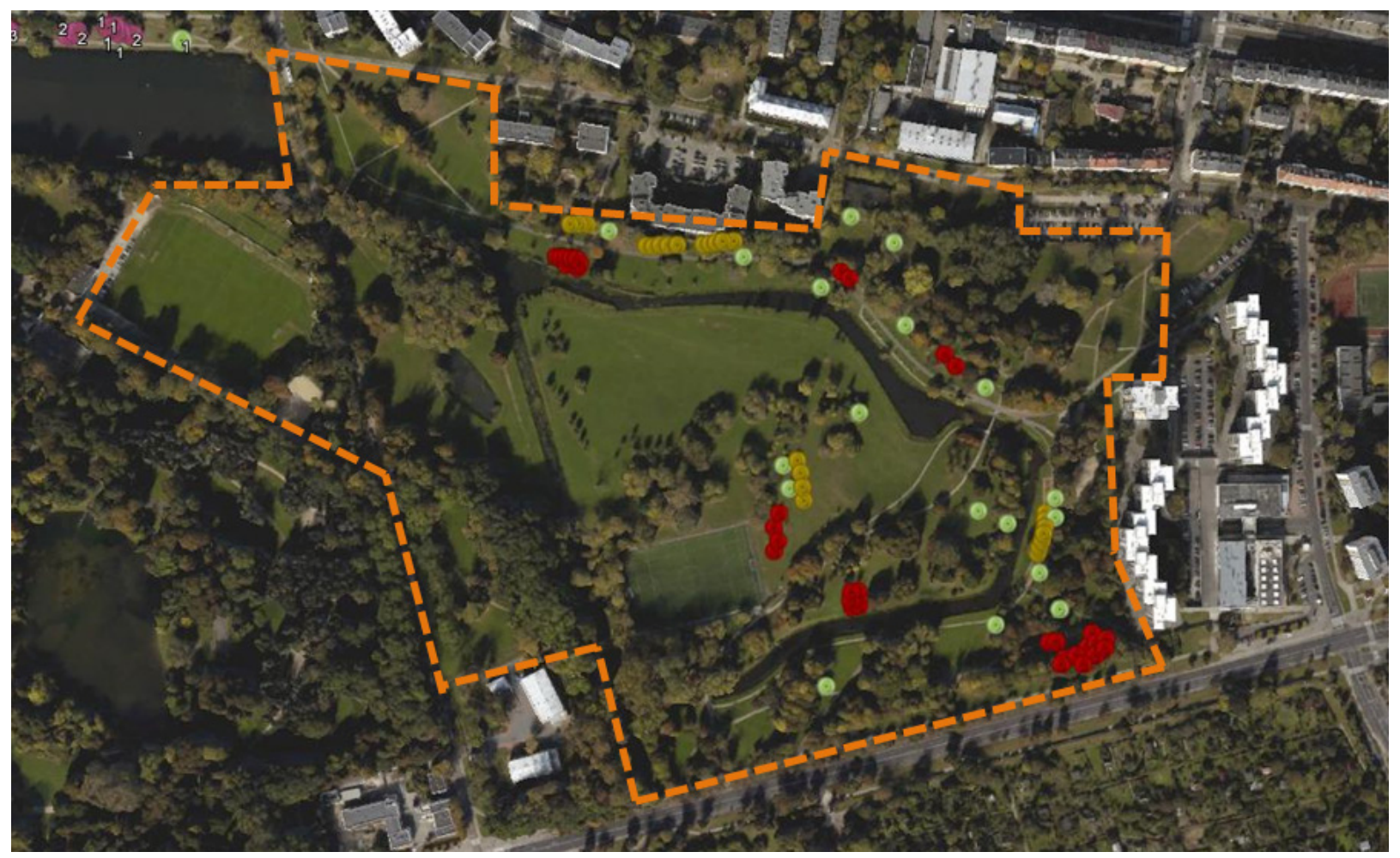

a.

Legend: Single trees $\mathbf{8}$ Group of trees $\bigcirc \bigcirc$ Linear structures of fruit trees

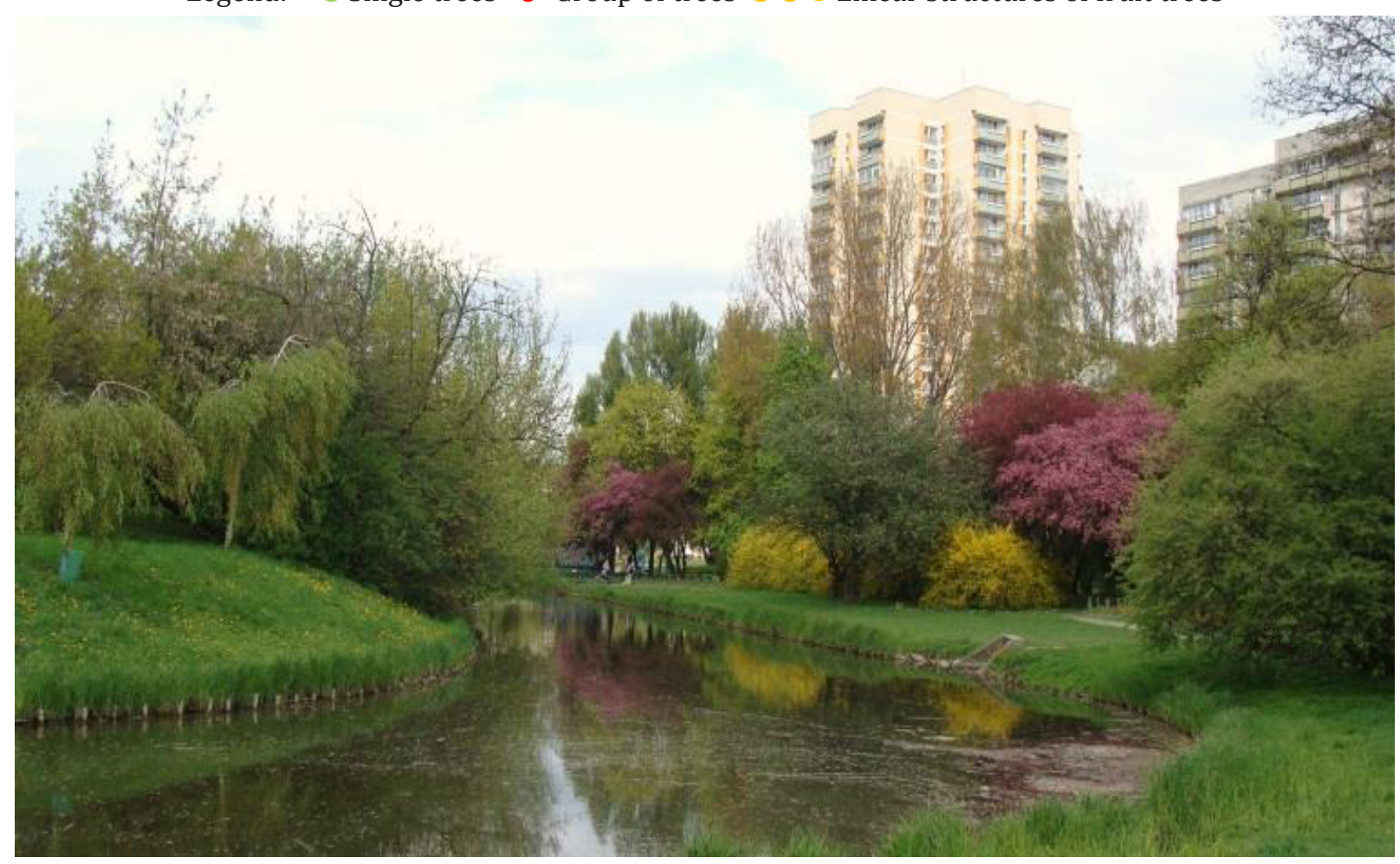

b.

Fig. 2. Waszyngtona Park, Warsaw: a) Site plan of the park with fruit tree compositions, b) Park perspective with plant groups consisting of fruit trees and other species of trees and shrubs (graphic and photo by T. Lisandru) 


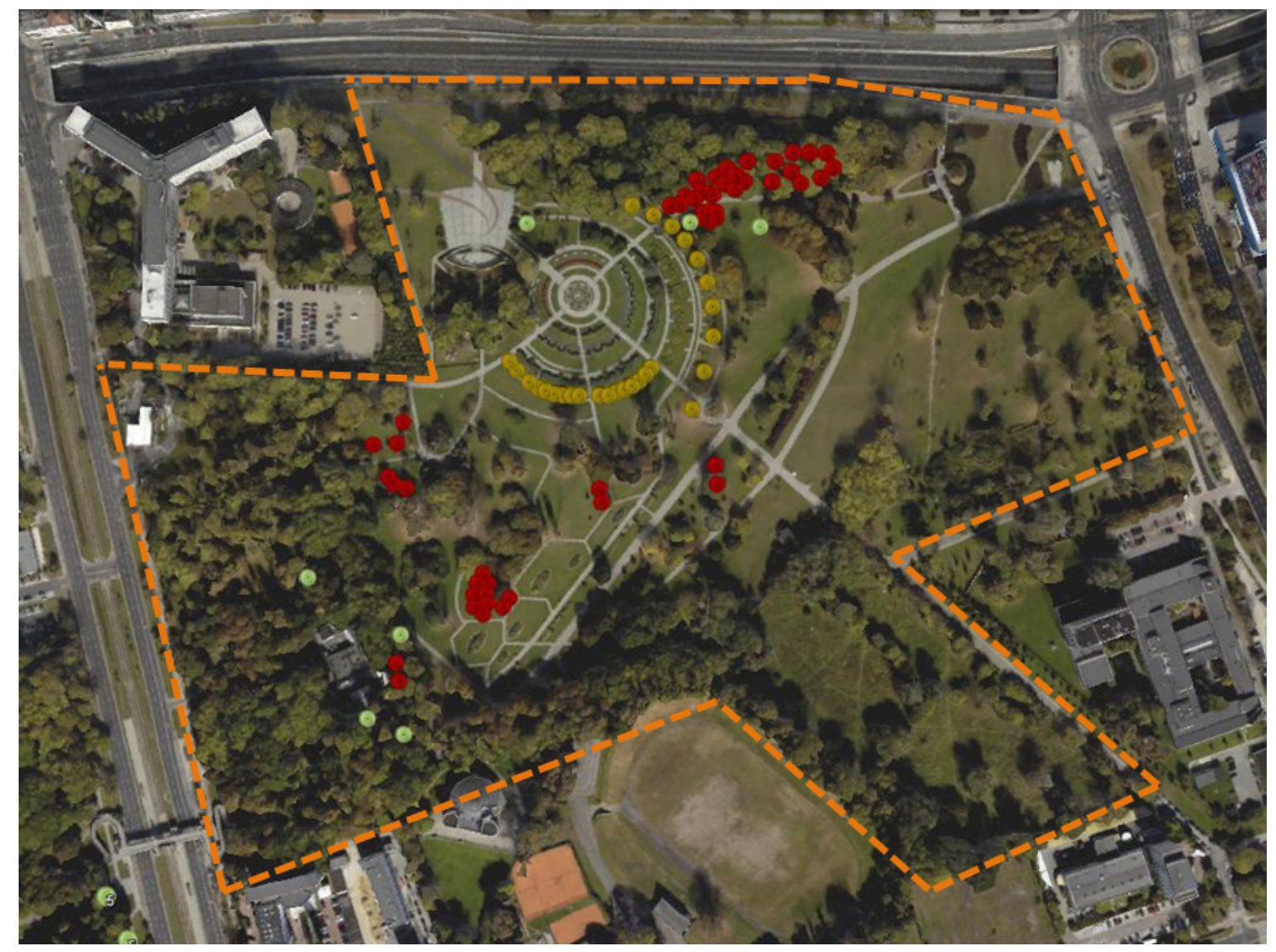

a.

Legend: Single trees $\bullet$ Group of trees $\bigcirc \bigcirc$ Linear structures of fruit trees

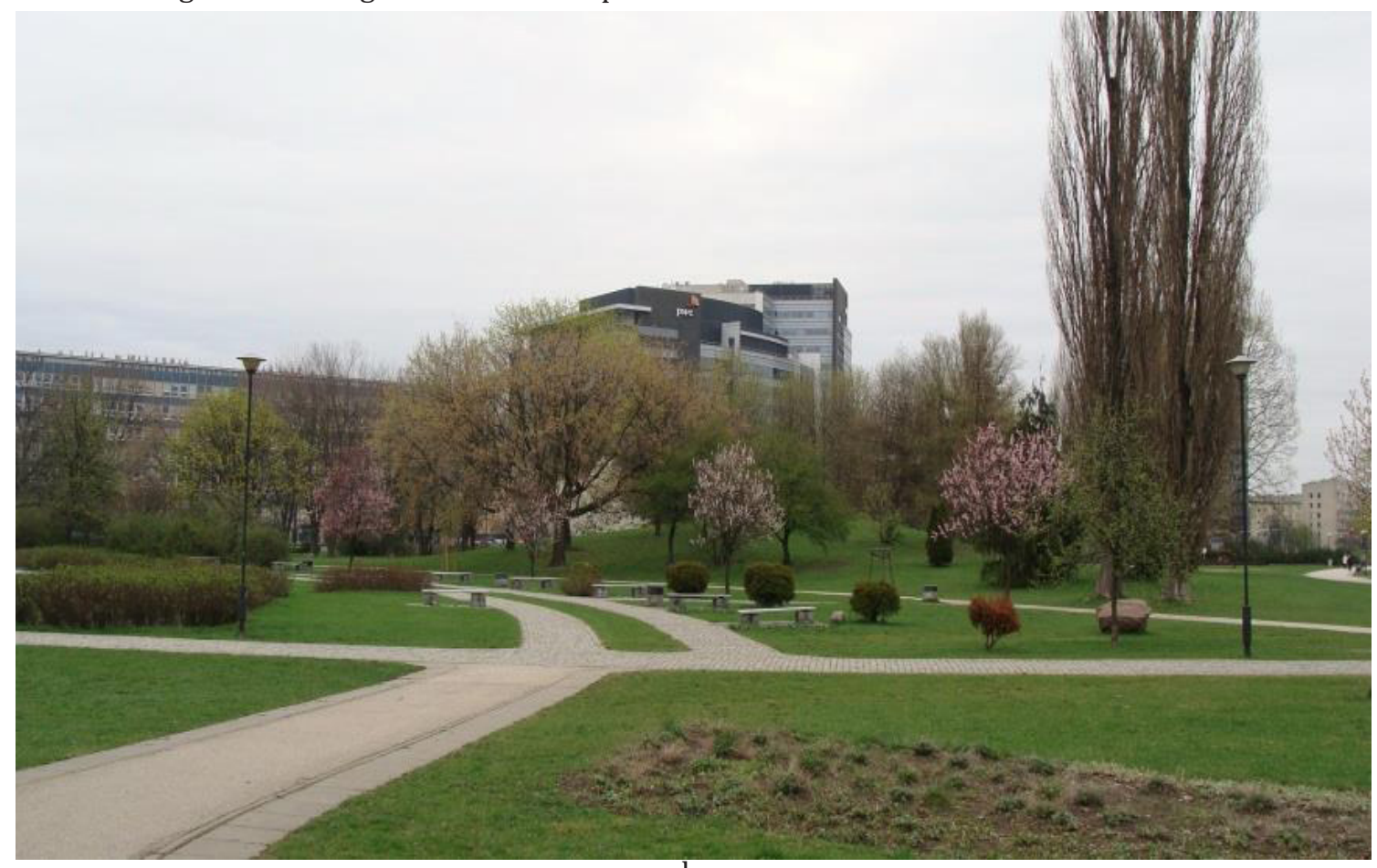

b.

Fig. 3. Pole Mokotowskie Park in Warsaw: a) Site plan of the park with fruit tree compositions, b) Park perspective with linear structure of fruit trees in the park - single row of trees (graphic and photo by T. Lisandru). 
the arrangement of utilitarian gardens created in different ages till today. Social and economic transformation of the $20^{\text {th }}$ and $21^{\text {st }}$ centuries forced gardeners and landscape architects to find new functions for fruit trees used not only in private gardens, but in public greenery (Draper and Friedman, 2010). The attention of urban planners, garden designers and communities today is more focused on ecological aspects (an application of fruit trees compositions to parks and gardens enhance the biodiversity) and utilitarian functions of edible landscapes including public spaces in the cities (Barthel et.al., 2015; Speaka et.al., 2015). Fruit trees planted in public parks become a part of it. Nevertheless, the ornamental and productive attributions of fruit trees found in three different plant compositions in historical and modern public parks in Warsaw are the proof that fruit trees can increase the compositional value of public greenery as much as other plants. The findings of this study are important for further investigations to be made on fruit tree identification in public areas and to define new functions for fruit trees, especially referring to their compositional value in public greenery establishment which has until now been ignored.

\section{CONCLUSIONS}

Fruit trees co-create the urban landscape and are used as essential elements of plant compositions in public areas. The examples shown above approve that individual fruit trees or planted in groups can have a positive effect on park structures. Different fruit tree compositions can have an influence on the following aspects: defining the spatial arrangement of the park, establishing scopes of park interiors and creating awesome perspectives of the parks. The single fruit tree can become an attractive natural dominant in park. Our results highlight the importance of fruit trees presence in public areas and both their values -ornamental and functional.

Based on this preliminary study, the research on fruit tree compositions can be continued in other green areas of Warsaw (green squares, pocket gardens, residential areas etc.) to identify all types of use of these trees in public spaces. Planting productive fruit trees in public parks will enrich the plant diversity of the area and will improve the quality and the attractiveness of public green areas in many cities. Their ornamental and productive qualities within parks should be properly appreciated.

\section{REFERENCES}

1. Barthel S, Parker J, Ernstson H (2015). Food and Green Space in Cities: A Resilience Lens on Gardens and Urban Environmental Movements. Urban Studies, 7: 1321-1338.

2. Baster P (2010). Drzewa i krzewy owocowe jako elementy kompozycji krajobrazowych w świetle polskich traktatów z XIX i początku XX wieku. [Fruit trees and shrubs as elements of landscape estates, described in Polish treatises of 19th and early 20th century]. Technical Transactions. Architecture, 8-A:119-126.

3. Draper C, Freedman D (2010). Review and Analysis of the Benefits, Purposes, and Motivations Associated with Community Gardening in the United States. Journal of Community Practice, 18: 4, 458-492.

4. Hobhouse P (2004). Plants in Garden History, Pavilion, London.

5. Jankowski E (1921). Korzyści z sadów, Warsaw.

6. Jankowski E (1930). Sad przy chacie, z rysunkami. Warsaw.

7. Majdecki L (2008). Historia ogrodów, T. 1, Od starożytności po barok. PWN, Warsaw.

8. Majdecki L (2009). Historia ogrodów, T. 2, Od XVIII wieku do współczesności, PWN, Warsaw.

9. Petzold E (1880). Sadzenie I prowadzenie drzew alejowych. Ogrodnik Polski, 1: 12-17.

10. Speaka AF, Mizgajski A, Borysiak J (2015). Allotment gardens and parks: Provision of ecosystem service with an emphasis on biodiversity. Urban Forestry \& Urban Greening, 14: 772-781.

11. Stagoll K, Lindenmayer DB, Knight E, Fischer J, Manning AD (2012). Large trees are keystone structures in urban parks. Conserv. Lett. 5(2): 115-122.

12. Zachariasz A (2012). Piękno i użyteczność - o sztuce uprawy roślin użytkowych. [Beauty and Utility - about the art of plants' cultivation]. Technical Transactions. Architecture, 8-A: 27-39. 